\title{
Применение шкалы гемероботолерантности для анализа антропогенной трансформации флоры Кузнецкого Алатау
}

\section{Using scales of hemeroby for research of anthropogenic transformation for flora of Kuznetskij Alatau}

\author{
Стрельникова Т. О., Хрусталева И. А. \\ Strelnikova T. O., Khrustaleva I. A. \\ Институт экологии человека СО РАН, Кузбасский ботанический сад, Кемерово, Россия. \\ E-mail: strelnikova21@yandex.ru; atriplex@rambler.ru \\ Institute of Human Ecology SB RAS, Kuzbass Botanical Garden, Kemerovo, Russia
}

\begin{abstract}
Peфepam. Статья содержит результаты изучения растительного покрова лесных низкогорий Кузнецкого Алатау. Полевые исследования выполнены в 2016-2018 гг. Проведен анализ антропогенной трансформации природных и техногенных ландшафтов. Анализ выполнен с использованием шкалы гемероботолерантности, разработанной для юга Сибири. В качестве индикаторов использованы интегральный индекс нарушенности и сопоставление долей высокотолерантных и низкотолерантных видов.
\end{abstract}

Ключевые слова. Биологическое разнообразие, интегральный индекс нарушенности, Кузнецкий Алатау, флора, шкала гемероботолерантности.

Summary. The article contains the results of studying the vegetation cover of the forest low mountains of the Kuznetskij Alatau. Field research was carried out in 2016-2018. The analysis of the transformation of natural and manmade landscapes is carried out. The analysis was performed using of plant indicator values of tolerability for hemeroby developed for the south of Siberia. An integral disturbance index and a comparison of the shares of high- and lowtolerability species were used as indicators.

Key words. Biological diversity, flora, integral disturbance index, Kuznetskij Alatau, scale values of tolerability for hemeroby.

Антропогенная трансформация природной среды является проблемой планетарного масштаба. Мониторинг показателей биологического разнообразия особенно актуален для устойчивого развития горнодобывающих регионов, таких как Кемеровская область, где сосредоточены основные запасы Кузнецкого угольного бассейна. На этой территории ежегодно добывается 76 \% коксующихся марок углей и свыше половины общего объема добываемого угля в России (Куприянов и др., 2008). Кузнецкий угольный бассейн расположен на уникальной в ландшафтном и биологическом отношении территории, которая является частью Алтае-Саянского экорегиона, характеризующегося повышенным биологическим разнообразием (Биологическое разнообразие ..., 2003). В последние два десятилетия интенсивно разрабатываются месторождения Междуреченского, Новокузнецкого, Ерунаковского угледобывающих районов (Потапов и др., 2005), сосредоточенные в низкогорных лесных ландшафтах Кузнецкого Алатау. Для характеристики биологического разнообразия угледобывающих районов Кемеровской области ранее были использованы индикаторы биоразнообразия (Платонова и др., 2018), предложенные для особо охраняемых территорий Алтае-Саянского экорегиона (Яшина, 2011). Показано, что для характеристики антропогенной трансформации флоры можно использовать соотношения индикаторов «доля адвентивных видов» и «доля редких видов», которые работают даже для небольших выборок, при исследованиях на локальном уровне (Стрельникова и др., 2018). Работы по созданию шкалы гемероботолерантности растений (Зверев и др., 2018) дают новый инструмент для мониторинга биологического разнообразия на юге Сибири. 
Выполнен анализ антропогенной трансформации флоры низкогорий Кузнецкого Алатау в целях совершенствования методических подходов к оценке и мониторингу биологического разнообразия горнодобывающих регионов.

В основы работы положены 177 полных геоботанических описаний, выполненных в трех вариантах (естественные ценозы, участки самозарастания и рекультивации на отвалах угольных разрезов) на трех мониторинговых полигонах. Сводные описания протестированы по шкале гемероботолерантности (Зверев и др., 2018) с использованием интегрированной информационной системы IBIS, версия 7.2 (Зверев, 2007). Названия видов в тексте приведены по сводке С. К. Черепанова (1995).

Мониторинговые полигоны расположены в юго-западной части Кузнецкого Алатау. Наиболее распространенными на этой территории являются лесные ландшафты низкогорий и долинные ландшафты малых рек. Небольшие площади занимают пихтовые с примесью липы леса, на высотных отметках 500-700 м. Участкам самозарастания и лесной рекультивации на отвалах Калтанского, Красногорского, Сибиргинского разрезов противопоставлены естественные ценозы близ п. Малиновка, г. Междуреченск, д. Чувашка. Антропогенное влияние в естественных ценозах проявляет последствия рекреационного, сельскохозяйственного использования и лесных рубок.

Число видов объединенной флоры 352, из них адвентивных - 26; 130 (36,7 \%) - присутствуют на всех трех мониторинговых полигонах. Представленность видов индикаторов гемеробии в исследуемой флоре составляет 99,4 \%, что говорит о высоком формальном соответствии шкалы для оценки растительного покрова в районе исследования. В нашем распоряжении находится тестовый вариант шкалы гемероботолерантности (представленный в программе IBIS, версия 7.2), в нем отсутствуют данные только для 2 видов, встречающихся на исследуемой территории - адвентивного Lupinus polyphyllus Lindl. и апофитного Pilosella novosibirskiensis Tupitzina; неполные (предварительные) статусы имеют еще 2 адвентивных вида - Oenothera rubricaulis Kleb. и Populus suaveolens Fisch. Интегральный индекс нарушенности для каждого варианта флоры представлен в таблице 1. Шкала гемероботолерантности является амплитудно-оптимумной, число градаций - 9. Показатели индекса нарушенности естественных местообитаний исследуемой территории $(3,9-3,6)$ близки аналогичным показателям, вычисленным А. А. Зверевым и соавторами (2018) для бассейнов Большой Теш $(3,9)$ и Уса $(2,8)$; тогда как показатели для вариантов самозарастания $(5,6-4,2)$ и рекультивации $(5,8-4,9)$ превышают средние данные для соответствующих речных бассейнов. Распределение оптимумов по градациям шкалы гемероботолерантности (табл. 2) ясно свидетельствует о росте доли видов, положительно реагирующих на антропогенное воздействие (градации шкалы 5-9) в техногенных экотопах (участки самозарастания и рекультивации на отвалах). Видов, имеющих низкую толерантность к антропогенным воздействиям (градации 2-3 в исследуемой флоре) - 15. Верхнюю границу на уровне 2 градации имеют лесные реликты Osmorhiza aristata (Thunb.) Rydb. и Sanicula europaea L.; на уровне 3 градации другие виды тенистых лесов Actaea erythrocarpa Fisch., A. spicata L., Asarum europaeum L., Bromopsis benekenii (Lange) Holub, Daphne mezereum L., Geranium krylovii Tzvel., Geranium robertianum L., Oxalis acetosella L., Polystichum braunii (Spenn.) Fee, Tilia sibirica Bayer; гигрофит Petasites radiatus (J.F.Gmel.) J.Toman; скальные растения Hylotelephium ewersii (Ledeb.) H.Ohba, Woodsia ilvensis (L.) R.Br. Еще 17 видов флоры могут мириться со слабым антропогенным воздействием (верхняя граница гемероботолерантности 4) - Bromopsis pumpelliana (Scribn.) Holub, Calamagrostis purpurea (Trin.) Trin., Carex diandra Schrank, Circaea lutetiana L., Corydalis bracteata (Steph.) Pers., Dactylorhiza hebridensis (Wilmott) Aver., D. longifolia (L.Neumann) Aver., Dryopteris expansa (C.Presl) Fraser-Jenk. \& Jermy, D. filix-mas (L.) Schott, Duschekia fruticosa (Rupr.) Pouzar, Festuca altissima All., Hypericum elegans Steph. ex Willd., Listera ovata (L.) R.Br., Ophioglossum vulgatum L., Phegopteris connectilis (Michx.) Watt, Saussurea latifolia Ledeb., Viola biflora L. Таким образом это наиболее уязвимая группа растений. Их встречаемость падает в техногенных экотопах, с 5до 0 \% у Hylotelephium ewersii, Sanicula europaea, Woodsia ilvensis; с 10-15 до 0-5 \% у Daphne mezereum, Osmorhiza aristata; с 40-65 до 0-10\% у Asarum europaeum, Oxalis acetosella. Высокотолерантные виды напротив увеличивают встречаемость на участках самозарастания и отвалах с 0-10 до 30-70 $\%$ у адвентивных Acer negundo L., Cirsium vulgare (Savi) Ten., Conyza canadensis (L.) Cronqist, Lactuca serriola L., Melilotus albus Medikus, Pastinaca sylvestris Mill., Tripleurospermum inodorum (L.) Sch.Bip. и апофитов гемерофитов Agrostis gigantea Roth, Amoria repens (L.) C.Presl, Cirsium setosum (Willd.) Besser, Sonchus arvensis L., Taraxacum officinale F.H.Wigg., Tussilago farfara L. 
Показатели видового богатства и нарушенности по вариантам

\begin{tabular}{|l|l|c|c|c|}
\hline \multicolumn{1}{|c|}{ Вариант } & Название полигона & Кол-во описаний & Кол-во видов & $\begin{array}{c}\text { Интегральный индекс } \\
\text { нарушенности }\end{array}$ \\
\hline естественные & Красногорский & 17 & 118 & 3,9 \\
\hline естественные & Сибиргинский & 20 & 166 & 3,9 \\
\hline естественные & Калтанский & 20 & 171 & 3,6 \\
\hline самозарастание & Красногорский & 20 & 164 & 4,7 \\
\hline самозарастание & Сибиргинский & 20 & 153 & 5,2 \\
\hline самозарастание & Калтанский & 20 & 123 & 5,6 \\
\hline рекультивация & Красногорский & 20 & 143 & 4,9 \\
\hline рекультивация & Сибиргинский & 20 & 127 & 5,3 \\
\hline рекультивация & Калтанский & 20 & 103 & 5,8 \\
\hline
\end{tabular}

Таблица 2

Распределение оптимумов в вариантах по градациям (от 1 до 9, в \%) шкалы гемероботолерантности

\begin{tabular}{|l|l|c|c|c|c|c|c|c|c|c|}
\hline \multicolumn{1}{|c|}{ Вариант } & Название полигона & 1 & 2 & 3 & 4 & 5 & 6 & 7 & 8 & 9 \\
\hline естественные & Красногорский & 0 & 22,8 & 37,2 & 10,1 & 8,4 & 5,8 & 3,3 & 5 & 7,4 \\
\hline естественные & Сибиргинский & 0 & 19,9 & 35,7 & 15,9 & 7,8 & 8,5 & 7,3 & 4,9 & 0 \\
\hline естественные & Калтанский & 0 & 29,2 & 33,2 & 13,9 & 9,3 & 3,4 & 6,3 & 4,1 & 0,6 \\
\hline самозарастание & Красногорский & 0 & 12,5 & 26,2 & 12,3 & 12,9 & 11,6 & 12,3 & 11,6 & 0,6 \\
\hline самозарастание & Сибиргинский & 0 & 9,5 & 19,5 & 13,1 & 9,5 & 11,1 & 19,5 & 17,1 & 0,7 \\
\hline самозарастание & Калтанский & 0 & 8,9 & 13,2 & 8,2 & 12,4 & 14,7 & 19,7 & 22,9 & 0 \\
\hline рекультивация & Красногорский & 0 & 12,7 & 21,5 & 13,7 & 11,6 & 11,9 & 13,7 & 14,9 & 0 \\
\hline рекультивация & Сибиргинский & 0 & 6,4 & 16,5 & 15,9 & 10,7 & 14,8 & 18,9 & 15,9 & 0,9 \\
\hline рекультивация & Калтанский & 0 & 5,9 & 11,9 & 6,9 & 14,7 & 17,6 & 22,4 & 20,6 & 0 \\
\hline
\end{tabular}

Таким образом, новая шкала гемероботолерантности растений юга Сибири является удобным инструментом, позволяющим проводить мониторинговые исследования за состоянием биологического разнообразия в горно-добывающих регионах, где природные системы подвергаются регулярным антропогенным изменениям. В качестве индикаторов можно использовать рассчитанные значения индекса нарушенности и соотношения групп высокотолерантных и низкотолерантных видов.

Благодарности. Работа выполнена в рамках государственного задания «Оценка состояния и охрана флористического разнообразия под влиянием антропогенных и техногенных факторов insitu и exsitu» № 0352-2019-0015; № госрегистрации АААА-А17-117041410053-1.

\section{ЛИТЕРАТУРА}

Биологическое разнообразие Алтае-Саянского экорегиона / Под ред. А. Н. Куприянова. - Кемерово, 2003. $156 \mathrm{c}$.

Зверев $\boldsymbol{A}$. $\boldsymbol{A}$. Информационные технологии в исследованиях растительного покрова: учеб. пособие. - Томск: ТМЛ-Пресс, 2007. - 304 с.

Зверев А. А., Шереметова С. А., Шереметов Р. Т. Шкала гемероботолерантности растений как инструмент для анализа флористических данных в рамках бассейнового подхода // Проблемы промышленной ботаники индустриально развитых регионов: Сб. материалов докладов V междунар. конф. (2-3 октября 2018 г., Кемерово). Кемерово, 2018. - С. 20-26.

Куприянов А. Н., Манаков Ю. А., Баранник Л. П. Восстановление экосистем на отвалах горнодобывающей промышленности Кузбасса. - Новосибирск: Наука, 2008. - 180 с. 
Платонова С. Г., Стрельникова Т. О., Скрипко В. В., Манаков Ю. А. Комплексная оценка угледобывающих районов в целях сохранения биоразнообразия // География и природные ресурсы, 2018. - № 3. - C. 49-58. DOI: 10.21782/GIPR0206-1619-2018-3(49-58)

Потапов В. П., Мазикин В. П., Сцастливцев Е. Л., Вашлаева Н. Ю. Геоэкология угледобывающих районов Кузбасса. - Новосибирск: Наука, 2005. - 660 с.

Стрельникова Т. О., Платонова С. Г., Скрипко В. В. Использование индексов биологического разнообразия для характеристики естественных и техногенных территорий // Проблемы ботаники Южной Сибири и Монголии: Сб. науч. ст. по материалам XVII междунар. науч.-практ. конф. (24-27 мая 2018 г., Барнаул). - Барнаул: Изд-во АлтГУ, 2018. - С. 393-396.

Черепанов $\boldsymbol{C}$. $\boldsymbol{K}$. Сосудистые растения России и сопредельных государств (в пределах бывшего СССР). СПб.: Мир и семья, 1995. - 992 с.

Яиина Т. В. Индикаторы оценки биоразнообразия на особо охраняемых природных территориях Алтае-Саянского экорегиона. - Красноярск, 2011. - 56 с. 